\title{
Left ventricular function in double inlet left ventricle before the Fontan operation: comparison with tricuspid atresia
}

\author{
ANDREW N REDINGTON, BRODIE KNIGHT, PAUL J OLDERSHAW, \\ ELLIOT A SHINEBOURNE, MICHAEL L RIGBY
}

From the Brompton Hospital, London

SUMMARY Fourteen patients with double inlet left ventricle and nine patients with tricuspid atresia had biplane left ventricular angiography with simultaneous measurement of left ventricular ${ }^{+}$ pressure by micromanometer. Age distribution, haemodynamic function, and previous palliative $\stackrel{\circ}{\supset}$ operation were similar in the two groups. Left ventricular volumes were calculated frame by frame $\vec{\circ}$ throughout the cardiac cycle by Simpson's rule. The end diastolic volume index was similar in the two groups, but the ejection fraction was significantly lower in tricuspid atresia. Left ventricularo peak filling and emptying rates were also lower in tricuspid atresia, although heart rates in the two groups were similar. End diastolic shape index was significantly higher in patients with tricuspid $\emptyset_{\infty}$ atresia, indicating a more globular shape, and changed less during systole, suggesting differences in ${ }^{\circ}$ the mechanism of ejection between the two groups. Analysis of pressure-volume loops showed normal phase relations between pressure and volume, but systolic stroke work was reduced in tricuspid atresia and correlated with stroke volume and shape change.

Left ventricular function was impaired in patients with tricuspid atresia when compared with those with double inlet left ventricle and this finding may reflect structural differences caused by the absence of one atrioventricular connection.

Various radical palliative procedures based on Fontan's original operation have been introduced to correct the circulation in patients with tricuspid atresia or double inlet left ventricle. ${ }^{12}$ It has been suggested that "normal" left ventricular function is of fundamental importance to survival after these procedures. ${ }^{3}$ More recently, however, several groups have shown depressed left ventricular ejection fraction in patients with tricuspid atresia both before and after primary palliative procedures such as systemic to pulmonary shunting and pulmonary artery banding. ${ }^{46}$ There is little published data on ventricular function in double inlet left ventricle but our own preliminary data have suggested that some indices of left ventricular function are normal or near normal in these patients. ${ }^{7}$ It is somewhat surprising, therefore, if ventricular function is an important determinant of outcome, that perioperative mortality is lower in

Requests for reprints to Dr Andrew N Redington, Department of Paediatric Cardiology, Brompton Hospital, Fulham Road, London SW3 6HP.

Accepted for publication 16 May 1988 patients with tricuspid atresia than in patients with double inlet left ventricle undergoing modified Fontan procedures. ${ }^{8}$

We studied left ventricular function in a group of $\frac{7}{\sigma}$ patients with double inlet left ventricle and compared 3 . these results with similar measurements in patients $\delta$ with tricuspid atresia in order to explore the possible causes of any differences between the two groups ando to assess the influence of ventricular function on the outcome of corrective surgery.

\section{Patients and methods}

\section{TERMINOLOGY}

The segmental approach to the classification of 0 univentricular hearts has been described in detailo elsewhere. ${ }^{9}$ In hearts with a univentricular connection the atrial chambers connect either entirely or $\stackrel{?}{?}$ predominantly to one ventricle. In all patients in this 0 study the atria connected to a main chamber of lefto ventricular morphology and the right ventricle was rudimentary.

Patients were described as having double inlet lefto 
ventricle when one atrioventricular valve and more than $50 \%$ of the other valve were connected to a morphologically left ventricle. Under these circumstances one or other of the atrioventricular valves may be stenotic, imperforate, straddling, or overriding; these additional abnormalities are described separately (table 1 ). When there was a common atrioventricular valve the connection was said to be double inlet when $>75 \%$ of the valve was connected to the left ventricle.

The other group had classic tricuspid atresia, that is absence of the right atrioventricular connection with interposition of sulcus tissue between right atrium and the rudimentary right ventricle. No patient had the much rarer abnormality of atrioventricular concordance with imperforate right atrioventricular valve. The distinction between these two abnormalities was made by cross sectional echocardiography according to previously described echocardiographic criteria. ${ }^{10}$

The position of the rudimentary right ventricle and the ventriculoarterial connection in each patient was determined by cross sectional echocardiography and angiography.
PATIENTS

Fourteen patients (mean age 73, range 4-216 months) with an echocardiographic diagnosis of double inlet left ventricle and nine patients (mean age 55, range 6-144 months) with tricuspid atresia underwent cardiac catheterisation. All patients were being assessed for suitability for the Fontan operation. Ten patients with double inlet left ventricle and six patients with tricuspid atresia were studied a mean (SD) of 32 (17) months after palliative procedures. Table 1 shows the full sequential diagnosis and details of previous operation for each patient.

\section{Cardiac catheterisation}

Cardiac catheterisation was performed during general anaesthesia. Table 2 summarises the haemodynamic data recorded before angiography. There were no significant differences between the groups for left ventricular peak systolic pressure, end diastolic pressure, or aortic oxygen saturations. Orthogonal biplane left ventricular cineangiograms were recorded on $35 \mathrm{~mm}$ cinefilm at a frame rate of 50 or 75 frames per second depending on the heart rate. A

Table 1 Sequential diagnosis and previous operation in 14 patients with double inlet left ventricle and nine with tricuspid atresia

\begin{tabular}{|c|c|c|c|c|c|}
\hline Patient & $A V$ connection * & $R V$ to $L V$ relation & $V A$ connection & Associated lesions & Operation \\
\hline \multicolumn{6}{|c|}{ Double inlet left ventricle } \\
\hline $\begin{array}{l}1 \\
2 \\
3\end{array}$ & $\begin{array}{l}2 \text { valves } \\
2 \text { valves } \\
\text { Imperforate right } \\
\text { AVV }\end{array}$ & $\begin{array}{l}\text { Right } \\
\text { Left } \\
\text { Right }\end{array}$ & $\begin{array}{l}\text { Concordant } \\
\text { Single outlet } \\
\text { Concordant }\end{array}$ & $\begin{array}{l}\text { Absent left PA } \\
\text { Pulmonary atresia } \\
-\end{array}$ & $\begin{array}{l}\text { Waterston shunt } \\
\text { Waterston and Blalock shunt } \\
-\end{array}$ \\
\hline 4 & 2 valves & Right & Discordant & $\begin{array}{l}\text { Subpulmonary stenosis } \\
\text { and valvar PS }\end{array}$ & - \\
\hline $\begin{array}{l}5 \\
6\end{array}$ & $\begin{array}{l}2 \text { valves } \\
2 \text { valves }\end{array}$ & $\begin{array}{l}\text { Left } \\
\text { Right }\end{array}$ & $\begin{array}{l}\text { Discordant } \\
\text { Discordant }\end{array}$ & $\begin{array}{l}\text { Valvar PS } \\
\text { Ao interruption }\end{array}$ & $\begin{array}{l}\text { Blalock shunt } \\
\text { Repaired Ao interruption, PA } \\
\text { band }\end{array}$ \\
\hline $\begin{array}{l}7 \\
8\end{array}$ & $\begin{array}{l}2 \text { valves } \\
\text { Common }\end{array}$ & $\begin{array}{l}\text { Left } \\
\text { Right }\end{array}$ & $\begin{array}{l}\text { Discordant } \\
\text { Disconcordant }\end{array}$ & $\overline{\text { Ao }}$ coarctation & $\begin{array}{l}\text { PA band } \\
\text { Repaired coarctation, } \\
\text { PA band (tight }++ \text { ) }\end{array}$ \\
\hline 9 & 2 valves & Right & Concordent & $\begin{array}{l}\text { Pulmonary vascular } \\
\text { disease }\end{array}$ & - \\
\hline $\begin{array}{l}10 \\
11\end{array}$ & $\begin{array}{l}2 \text { valves } \\
2 \text { valves }\end{array}$ & $\begin{array}{l}\text { Right } \\
\text { Left }\end{array}$ & $\begin{array}{l}\text { Discordant } \\
\text { Discordant }\end{array}$ & & $\begin{array}{l}\text { Repaired coarctation } \\
\text { PA band }\end{array}$ \\
\hline 12 & 2 valves & Right & Discordant & $\begin{array}{l}\text { Ao interruption, } \\
\text { restrictive VSD }\end{array}$ & $\begin{array}{l}\text { Repaired Ao interruption, } \\
\text { enlarged VSD, PA band }\end{array}$ \\
\hline $\begin{array}{l}13 \\
14\end{array}$ & $\begin{array}{l}2 \text { valves } \\
2 \text { valves }\end{array}$ & $\begin{array}{l}\text { Right } \\
\text { Left }\end{array}$ & $\begin{array}{l}\text { Discordant } \\
\text { Double outlet LV }\end{array}$ & $\overline{\mathbf{P S}}$ & $\begin{array}{l}\text { PA band } \\
\text { Shunt }\end{array}$ \\
\hline $\begin{array}{l}15 \\
16\end{array}$ & $\begin{array}{l}\text { Tricuspid atresia } \\
\text { Tricuspid atresia }\end{array}$ & & $\begin{array}{l}\text { Tricuspid atresia } \\
\text { Discordant } \\
\text { Double outlet RV }\end{array}$ & $\begin{array}{l}\text { Restrictive VSD } \\
\text { Subpulmonary stenosis, } \\
\text { pulmonary valve } \\
\text { stenosis }\end{array}$ & $\begin{array}{l}\text { PA band } \\
\text { Shunt }\end{array}$ \\
\hline $\begin{array}{l}17 \\
18 \\
19 \\
20 \\
21 \\
22 \\
23\end{array}$ & $\begin{array}{l}\text { Tricuspid atresia } \\
\text { Tricuspid atresia } \\
\text { Tricuspid atresia } \\
\text { Tricuspid atresia } \\
\text { Tricuspid atresia } \\
\text { Tricuspid atresia } \\
\text { Tricuspid atresia }\end{array}$ & & $\begin{array}{l}\text { Concordant } \\
\text { Concordant } \\
\text { Double outlet RV } \\
\text { Discordant } \\
\text { Discordant } \\
\text { Concordant } \\
\text { Single outlet }\end{array}$ & $\begin{array}{l}\text { Subpulmonary stenosis } \\
\text { Subpulmonary stenosis } \\
= \\
= \\
\overline{\text { Pulmonary atresia }}\end{array}$ & $\begin{array}{l}\text { Shunt } \times 2 \\
\text { Shunt } \\
\text { Band } \\
\text { Band } \\
\text { PA band } \\
\text { Shunt } \\
\text { Shunt } \times 2\end{array}$ \\
\hline
\end{tabular}

^All patients have situs solitus.

PA, pulmonary artery; Ao, artic; PS, pulmonary stenosis; VSD, ventricular septal defect; AVV, atrioventricular valve; RV, right ventricle; $L V$, left ventricle. 
Table 2 Haemodynamic data (mean (SD)) recorded before angiography

\begin{tabular}{|c|c|c|c|}
\hline & $\begin{array}{l}\text { Tricuspid } \\
\text { atresia }\end{array}$ & $\begin{array}{l}\text { Double inlet } \\
\text { left ventricle }\end{array}$ & $p$ \\
\hline $\begin{array}{l}\text { Peak LV systolic pressure }(\mathrm{mm} \mathbf{H g}) \\
\mathrm{LV} \text { end diastolic pressure }(\mathrm{mm} \mathbf{H g}) \\
\text { Aortic oxygen saturation }(\%)\end{array}$ & $\begin{array}{r}100(24) \\
9(4) \\
86(3)\end{array}$ & $\begin{array}{r}108(21) \\
8(4) \\
84(8)\end{array}$ & $\begin{array}{l}\text { NS } \\
\text { NS } \\
\text { NS }\end{array}$ \\
\hline
\end{tabular}

LV, left ventricular.

mark, coinciding with the $\mathbf{R}$ wave of the patient's electrocardiogram, was recorded on the cinefilm. After the position of the rudimentary ventricle had been displayed by echocardiography, the angiographic projections were selected to show the interventricular septum. The projections selected were direct anteroposterior and lateral when the rudimentary chamber was to the left of the main chamber and $30^{\circ}$ right anterior oblique- $60^{\circ}$ left anterior oblique when it was to the right. In 12 of the patients with double inlet left ventricle and in five with tricuspid atresia left ventricular pressure was measured with a micromanometer tipped catheter (Millar Instruments) during ventriculography. The output of this catheter was recorded at a paper speed of $200 \mathrm{~mm} / \mathrm{s}$ along with an electrocardiogram and an event mark that coincided with the appearance of contrast medium in the ventricle. Thus it was possible to synchronise the angiogram and pressure recordings. At the end of the study the patient was moved $10 \mathrm{~cm}$ with a catheter in the left ventricle for later calibration of the cinefilm.

\section{ANALYSIS OF ANGIOGRAMS}

Only normally conducted beats were analysed. Extrasystoles and post-extrasystoles were excluded. Our method of analysis has been described in detail previously." Briefly, successive cineframes were projected on to a Summagraphics digitising plate interfaced with a Prime 750 computer. The left ventricular outline, excluding the rudimentary right ventricle, was traced frame by frame, starting and finishing with frames corresponding to the $R$ wave of the electrocardiogram. Approximately $100 \mathrm{x}, \mathrm{y}$ coordinates were recorded for each outline and stored on magnetic tape for later analysis. This procedure was repeated for the same cycle in the other angiographic view and finally the corresponding left ventricular pressure trace was digitised on the same equipment.

From this stored data the following were derived:

\section{Left ventricular volume}

Because the shape and position of these ventricles are abnormal it is inappropriate to measure their volume from single plane angiograms according to the geometric assumptions derived from the normal left
Redington, Knight, Oldershaw, Shinebourne, Rig然 ventricle. In this study we calculated ventricul: volume from the orthogonal biplane angiogranis using Simpson's rule. This is a multiple slice methot which overcomes some of the geometric assumptions inherent in other methods of calculating left vettricular volume. Although no angiographic method perfect, our method, previously described in detaif, was accurate when compared with left ventriculat cast volumes measured by fluid displacement f $^{2}$ Briefly, the left ventricle was divided into 40 equa slices along its long axis. The cross sectional area of each segment was assumed to be an ellipse and itgs major and minor dimensions were calculated from each of the angiographic views. The volume of the ventricle was derived from the sum of the volume of each slice by applying Simpson's rule (fig 1).

Ventricular volume was measured frame by frame throughout the cardiac cycle and displayed along with its first derivative, dVol/dT (fig 2). End diastolic and end systolic volumes were later corrected for body surface area and expressed in $\mathrm{ml} / \mathrm{m}^{2}$. The ejection fraction was calculated in the usual way. Peak rates of ventricular filling and emptying were taken as the maximum positive and negative defle $\bullet$ tions on the first derivative of the volume-time curve and were normalised by dividing by end diastolio volume (units $=\mathrm{s}^{-1}$ ).

\section{Ventricular shape index}

This is a measure of the roundness of the outline of the ventricular cavity (fig 2 ) that is independent of volume. Calculated as $4 \pi$ (cavity area)/(perimeter $\overline{2}$ $\times 100$ it has a maximum value of 100 when the cavit outline is circular and 0 when the cavity is obliterated. The normal left ventricle shows progressive reduction in shape index throughout systole, as it becomes a less circular shape. ${ }^{11}$ In this study end diastolic, end systolic, and percentage systolic change were taken as an average of the two angiographic views.

\section{Pressure-volume relations}

The frame by frame measurement of ventricula volume has been described above. The derived volume-time curve and the simultaneous digitised pressure trace were combined to give an instantant eous pressure-volume loop. The left ventricular systolic stroke work performed on the circulationds equal to the area enclosed by the loop ${ }^{13}$ and this wक्षु measured by automatic planimetry and expressed $\mathfrak{m}$ $\mathrm{J} /$ beat $/ \mathrm{m}^{2}$ body surface area $\left(1 \mathrm{~J}=1.36 \times 10^{-4} \mathrm{~mm}\right.$ Hg.ml). The cycle efficiency of the loops was expressed as a ratio of the area of the loop to that of a squase or rectangle that just encloses it ${ }^{14}$ (that is the ratio $\vec{g}^{f}$ actual work done to the maximum possible for 

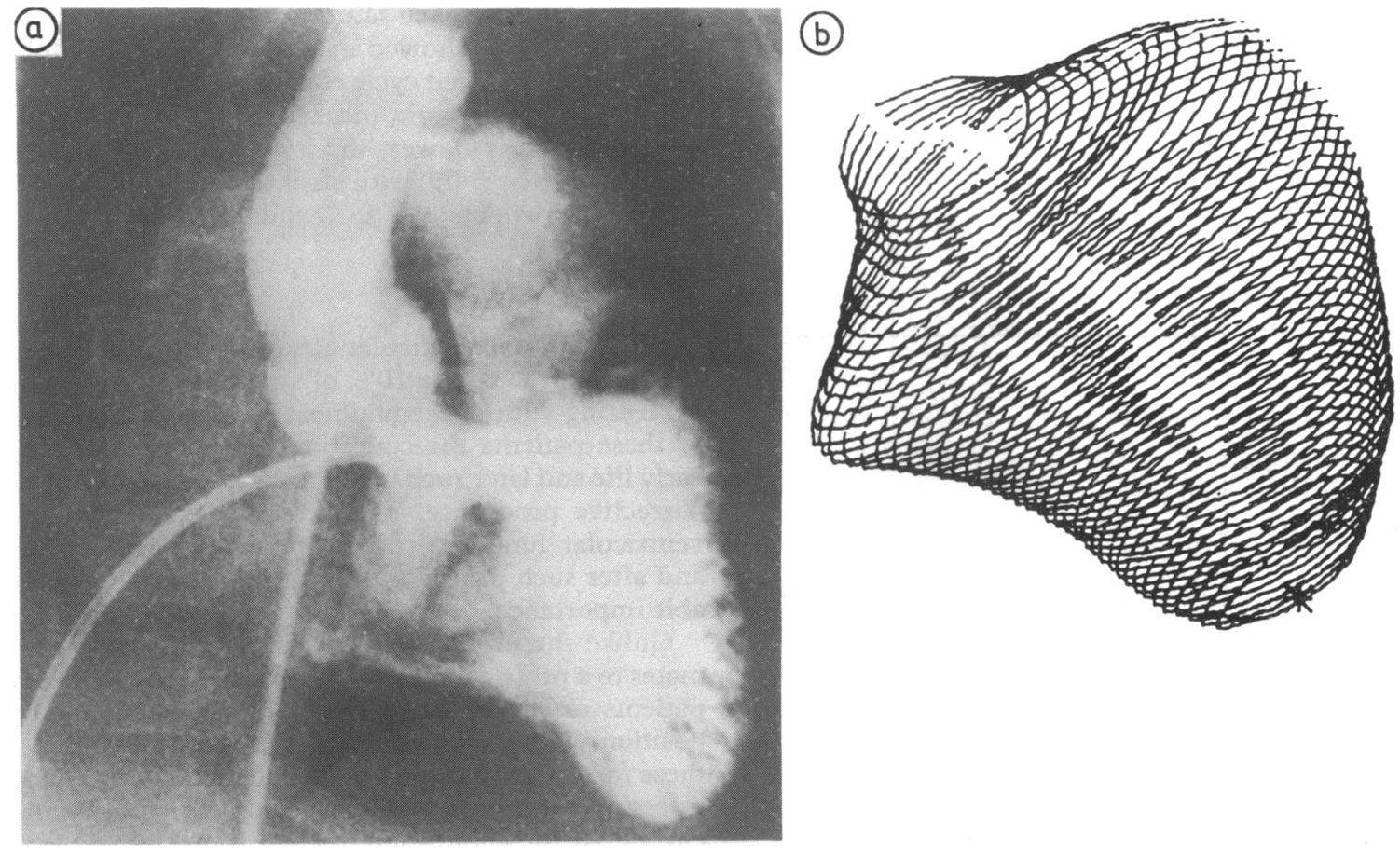

Fig 1 Left ventricular angiogram for patient 1 (a) with computer derived three-dimensional construction (b) from which volume calculations were made. Accurate reproduction of the ventricular shape and contour is possible.

ventricle with the same stroke volume and pressure change).

\section{STATISTICAL ANALYSIS}

Group data were compared by standard $t$ tests and the null hypothesis was rejected when $\mathrm{p}<0.05$. We used linear regression analysis by the method of least squares to examine correlations between variables.

\section{Results}

No patient had important atrioventricular valve regurgitation. Table 3 summarises the data derived from the angiograms. Mean (SD) end diastolic volume was $136(32)$ and $129(40) \mathrm{ml} / \mathrm{m}^{2}$ for the groups with double inlet left ventricle and tricuspid atresia respectively ( $p=N S$ ). End systolic volume, however, was significantly lower in patients with double inlet left ventricle (45 (18) v $64(26) \mathrm{ml} / \mathrm{m}^{2}$ $(p=<0.05))$. Thus ejection fraction was higher in the double inlet group (74 (9) $v 51(6.5) \%, p$ $<0.001)$. Furthermore, nine patients in the double inlet group had an ejection fraction of $\geqslant 75 \%$ and only one patient had an ejection fraction of $<60 \%$. In contrast none of the patients with tricuspid atresia had an ejection fraction of $>60 \%$ (fig 3 ). There were no differences in ventricular volumes or ejection fraction when patients in the various operative subgroups were compared and there was no significant relation between ejection fraction and age, age at or time from operation, or aortic oxygen saturation for either group.

The ventricular shape index at end diastole (averaged from the two angiographic views) was higher in tricuspid atresia (88) (6) $v 81(6) \mathrm{p}<0.05)$, indicating a more globular shape. Systolic shape index change in patients with tricuspid atresia was reduced $(5 \cdot 8(4.3) v 18(7) \%, p<0.001)$, suggesting differences in the mechanism of ejection between the two groups. There was a significant correlation between systolic shape index change and ejection fraction (all patients, $r=0.63, p<0.02$ ).

Peak rates of ventricular filling corrected for end diastolic volume were $5.9(2.5)$ and $4.1(1.2) \mathrm{s}^{-1}$ for the groups with double inlet or tricuspid atresia respectively $(p<0.05)$. There was a strong negative correlation between peak filling rate and $R R$ interval in the patients with double inlet left ventricle $(r=-0.72, p<0.001)$ but not in those with tricuspid atresia $(r=-0.47, p=N S)$. Time to peak filling rate was less in tricuspid atresia $(66(22) v 82$ (40) $\mathrm{ms}$ ) but this difference did not reach statistical significance. The peak rate of ventricular emptying was also reduced in patients with tricuspid atresia 

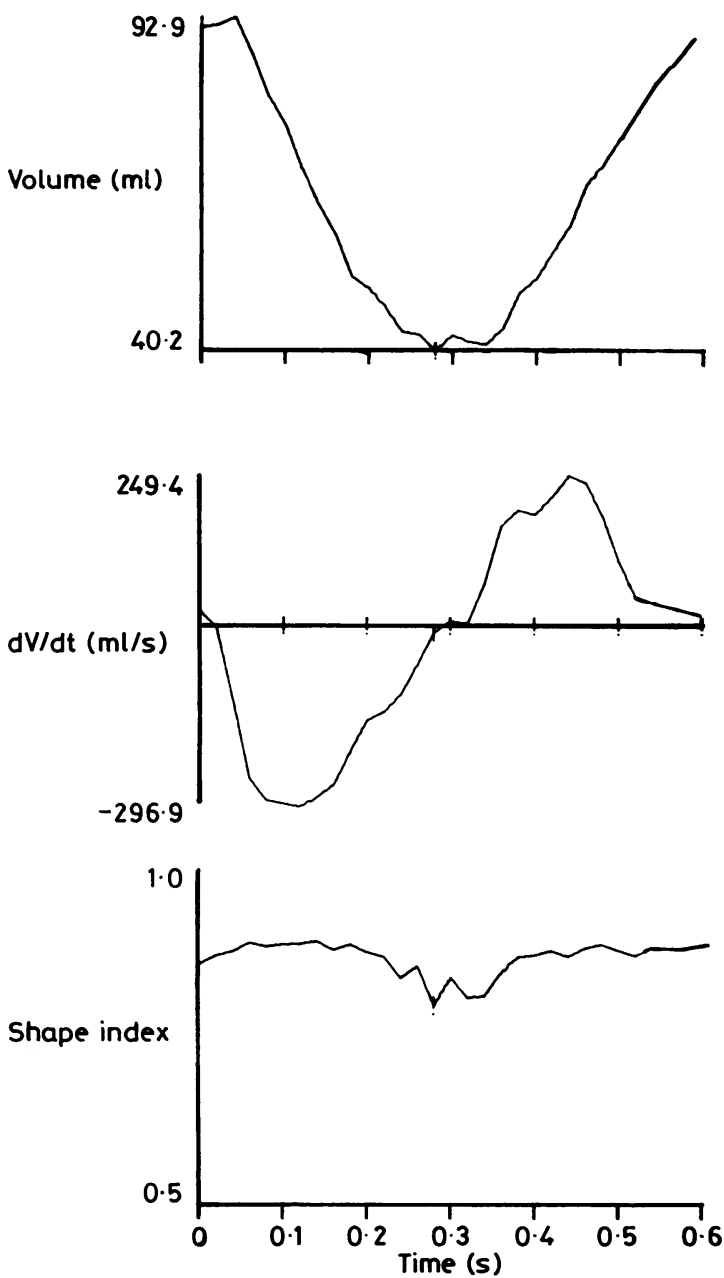

Fig 2 Typical plots showing left ventricular volume, rate of change of volume, and shape index throughout the cardiac cycle.

$(3.4(1.2) v 5.2(2.6), \mathrm{p}<0.05)$ but there was no difference in time to peak ejection rate between the two groups.

\section{PRESSURE-VOLUME RELATIONS}

Pressure-volume loops were constructed in five of the patients with tricuspid atresia and in 12 with double inlet left ventricle. In all but one of the patients the loops showed a coordinate phase relation between pressure and volume, and cycle efficiency was similar in the two groups ( $p=N S$ ) and similar to that measured in the normal left ventricle. ${ }^{7}$ In patient 8 , who showed profoundly reduced pulmonary blood flow and severe systemic desaturation at catheterisation (oxygen saturation $=62 \%$ ), the pressure-volume loop showed an abnormal diastolic limp with a much reduced cycle efficiency ( $45 \%$ ).

Systolic stroke work, measured by planimetry \&f the loops, was lower in tricuspid atresia and correlated $(p<0.05)$ with stroke volume and shape change (all patients, $r=0.73$ and 0.7 respectively)?

\section{Discussion}

Infants with univentricular atrioventricular conneç tion account for up to $10 \%$ of symptomatic patients presenting with congenital heart disease. ${ }^{15}$ In many of these patients the condition can be palliated in early life and later such patients may be suitable for:a corrective procedure. The accurate assessment of ventricular function in these patients, both before and after such procedures, is therefore of consider ${ }^{2}$ able importance.

Unlike the normal left ventricle, which approxi mates to a prolate ellipsoid, the left ventricle in thes patients may vary considerably in size, shape, and position. Whatever method of measurement is used these factors are likely to influence the results whes assessing ventricular function from angiograms. In particular, the application of algorithms derived for the measurement of normal left ventricular volumio from single plane angiograms is not valid. In th study we used a computer assisted method to measure left ventricular volume from biplane angiograms using a modification of Simpson's rule

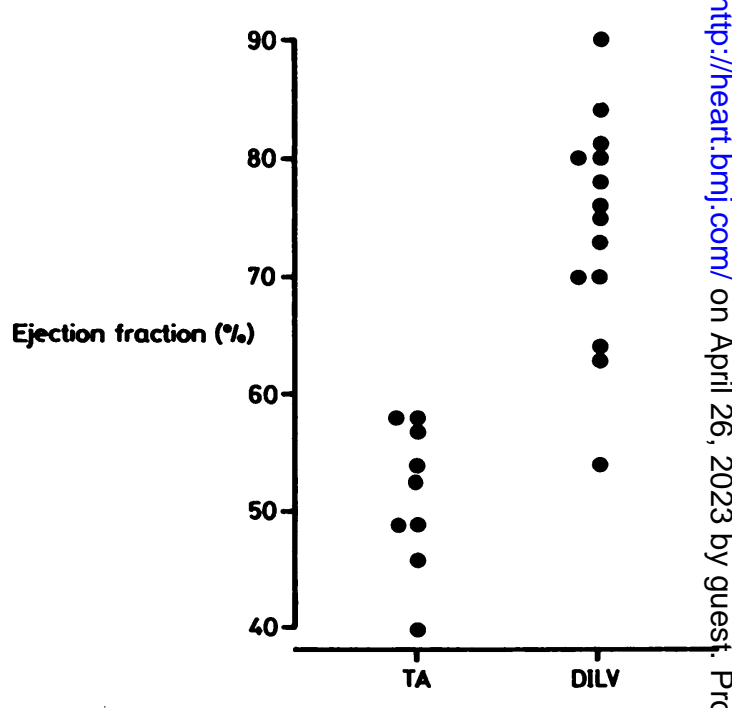

Fig 3 Left ventricular ejection fraction in tricuspid atresia (TA) compared with double inlet left ventricle (DILV). The ejection fraction was lower in patients with tricuspid atresia. 
Table 3 Angiographic data on patients with tricuspid atresia or double outlet left ventricle

\begin{tabular}{|c|c|c|c|c|c|c|c|c|c|c|c|c|c|c|c|}
\hline Patient & Age & $\begin{array}{l}B S A \\
\left(m^{2}\right)\end{array}$ & $\begin{array}{l}E D V I \\
\left(m l / m^{2}\right)\end{array}$ & $\begin{array}{l}E S V I \\
\left(m l / m^{2}\right)\end{array}$ & $\begin{array}{l}S V I \\
\left(\mathrm{ml} / \mathrm{m}^{2}\right)\end{array}$ & $\begin{array}{l}E \boldsymbol{F} \\
(\%)\end{array}$ & $E D S I$ & $\underset{(\%)}{\Delta S I}$ & $\begin{array}{l}P F R \\
\mid E D V\end{array}$ & $\begin{array}{l}\text { tPFR } \\
(m s)\end{array}$ & $\begin{array}{l}P E R \\
\mid E D V\end{array}$ & $\begin{array}{l}\text { tPER } \\
\text { (ms) }\end{array}$ & $\underset{\left(J / \text { beat } / m^{2}\right)}{S S W}$ & $\begin{array}{l}R R \\
\text { interval }\end{array}$ & $C E$ \\
\hline \multicolumn{16}{|c|}{ Double inlet left ventricle } \\
\hline $\begin{array}{c}1 \\
2 \\
3 \\
4 \\
5 \\
6 \\
7 \\
8 \\
9 \\
10 \\
11 \\
12 \\
13 \\
14 \\
\text { Mean } \\
\text { (SD) }\end{array}$ & $\begin{array}{r}216 \\
192 \\
121 \\
96 \\
42 \\
42 \\
36 \\
24 \\
25 \\
22 \\
10 \\
4 \\
156 \\
41 \\
73 \\
(70)\end{array}$ & $\begin{array}{l}1.44 \\
1.41 \\
0.92 \\
0.87 \\
0.6 \\
0.63 \\
0.58 \\
0.4 \\
0.51 \\
0.47 \\
0.5 \\
0.24 \\
1.18 \\
0.58\end{array}$ & $\begin{array}{l}132 \\
135 \\
138 \\
224 \\
135 \\
134 \\
163 \\
118 \\
117 \\
141 \\
147 \\
108 \\
82 \\
136 \\
136 \\
(32)\end{array}$ & $\begin{array}{l}40 \\
29 \\
22 \\
80 \\
27 \\
31 \\
15 \cdot 5 \\
35 \\
22 \\
38 \\
36 \\
21 \\
30 \\
62 \\
45 \\
(18)\end{array}$ & $\begin{array}{c}92 \\
106 \\
116 \\
144 \\
108 \\
103 \\
147 \cdot 5 \\
83 \\
95 \\
103 \\
111 \\
87 \\
52 \\
74 \\
101 \\
(25)\end{array}$ & $\begin{array}{l}70 \\
78 \\
84 \\
64 \\
80 \\
76 \\
90 \\
70 \\
81 \\
73 \\
75 \\
80 \\
63 \\
54 \\
74 \\
(9)\end{array}$ & $\begin{array}{l}89 \\
76 \\
91 \\
76 \\
74 \\
76 \\
90 \\
80 \\
79 \\
87 \\
78 \\
76 \\
76 \\
88 \\
81 \\
(6)\end{array}$ & $\begin{array}{c}18 \\
20 \\
21 \\
15 \\
18 \\
12 \\
36 \\
12 \\
10 \\
20 \\
21 \\
24 \\
13 \\
9 \\
18 \\
(7)\end{array}$ & $\begin{array}{r}5 \cdot 3 \\
4 \cdot 4 \\
3 \cdot 6 \\
4 \cdot 1 \\
12 \cdot 1 \\
4.6 \\
8 \cdot 5 \\
3.8 \\
7 \cdot 2 \\
5 \cdot 3 \\
6 \cdot 1 \\
8.4 \\
3.3 \\
5.4 \\
5.9 \\
(2.5)\end{array}$ & $\begin{array}{r}110 \\
50 \\
180 \\
-20 \\
100 \\
45 \\
40 \\
90 \\
90 \\
90 \\
100 \\
70 \\
80 \\
82 \\
(40)\end{array}$ & $\begin{array}{r}3 \cdot 2 \\
4 \cdot 4 \\
4.4 \\
4 \cdot 1 \\
8 \cdot 0 \\
4.0 \\
6.9 \\
3 \cdot 5 \\
4.5 \\
5 \cdot 1 \\
4 \cdot 1 \\
13 \cdot 1 \\
3 \cdot 2 \\
5.0 \\
5 \cdot 2 \\
(2 \cdot 6)\end{array}$ & $\begin{array}{r}80 \\
110 \\
50 \\
170 \\
80 \\
30 \\
30 \\
210 \\
60 \\
105 \\
110 \\
100 \\
130 \\
50 \\
94 \\
(51)\end{array}$ & $\begin{array}{l}0.92 \\
1.03 \\
1.06 \\
0.79 \\
1.20 \\
1.40 \\
0.28 \\
0.68 \\
0.75 \\
0.87 \\
0.40 \\
0.50 \\
0.82 \\
(0.33)\end{array}$ & $\begin{array}{l}660 \\
580 \\
720 \\
640 \\
300 \\
540 \\
460 \\
640 \\
560 \\
580 \\
400 \\
400 \\
470 \\
410 \\
530 \\
(120)\end{array}$ & $\begin{array}{l}64 \\
64 \\
72 \\
53 \\
72 \\
81 \\
45 \\
72 \\
62 \\
81 \\
69 \\
53 \\
67 \cdot 5 \\
(9 \cdot 2)\end{array}$ \\
\hline \multicolumn{16}{|c|}{ Tricuspid atresia } \\
\hline $\begin{array}{l}15 \\
16 \\
17 \\
18 \\
19 \\
20 \\
21 \\
22 \\
23\end{array}$ & $\begin{array}{r}42 \\
36 \\
36 \\
25 \\
98 \\
6 \\
59 \\
144 \\
51\end{array}$ & $\begin{array}{l}0.55 \\
0.56 \\
0.54 \\
0.6 \\
0.94 \\
0.26 \\
0.81 \\
1.2 \\
0.77\end{array}$ & $\begin{array}{r}153 \\
151 \\
213 \\
83 \\
101 \\
107 \\
140 \\
101 \\
108\end{array}$ & $\begin{array}{r}64 \\
63 \\
127 \\
38 \\
43 \\
54 \\
71 \\
54 \\
60\end{array}$ & $\begin{array}{l}89 \\
88 \\
86 \\
45 \\
58 \\
53 \\
69 \\
47 \\
48\end{array}$ & $\begin{array}{l}58 \\
58 \\
40 \\
54 \\
57 \\
49 \\
50 \\
46 \\
46\end{array}$ & $\begin{array}{l}98 \\
90 \\
94 \\
84 \\
86 \\
88 \\
90 \\
78 \\
86\end{array}$ & $\begin{array}{r}9 \\
12 \\
0 \\
0 \\
4 \\
8 \\
3 \\
6 \\
10\end{array}$ & $\begin{array}{l}6 \cdot 6 \\
5.0 \\
3 \cdot 4 \\
2 \cdot 7 \\
4.1 \\
3 \cdot 7 \\
5.0 \\
3 \cdot 3 \\
3 \cdot 3\end{array}$ & $\begin{array}{r}65 \\
50 \\
50 \\
90 \\
100 \\
60 \\
90 \\
30 \\
60\end{array}$ & $\begin{array}{l}4 \cdot 25 \\
3.0 \\
2 \cdot 2 \\
2.5 \\
3.4 \\
3.3 \\
1.7 \\
4.7 \\
5.2\end{array}$ & $\begin{array}{r}25 \\
170 \\
150 \\
160 \\
30 \\
90 \\
120 \\
20 \\
50\end{array}$ & $\begin{array}{l}0.52 \\
0.84 \\
\overline{-} \\
0.37 \\
0.26 \\
\overline{-} \\
0.45\end{array}$ & $\begin{array}{l}460 \\
580 \\
540 \\
640 \\
500 \\
500 \\
580 \\
500 \\
600\end{array}$ & $\begin{array}{l}55 \\
77 \\
- \\
59 \\
64 \\
\frac{-}{66}\end{array}$ \\
\hline $\begin{array}{l}\text { Mean } \\
\text { (SD) }\end{array}$ & $\begin{array}{r}55 \\
(42)\end{array}$ & & $\begin{array}{l}129 \\
(40)\end{array}$ & $\begin{array}{r}64 \\
(26)\end{array}$ & $\begin{array}{c}65 \\
(19)\end{array}$ & $\begin{array}{l}51 \\
(6 \cdot 5)\end{array}$ & $\begin{array}{l}88 \\
(6)\end{array}$ & $\begin{array}{r}5 \cdot 8 \\
(4 \cdot 3)\end{array}$ & $\begin{array}{c}4 \cdot 1 \\
(1 \cdot 2)\end{array}$ & $\begin{array}{r}66 \\
(22)\end{array}$ & $\begin{array}{c}3 \cdot 4 \\
(1 \cdot 2)\end{array}$ & $\begin{array}{c}91 \\
(61)\end{array}$ & $\begin{array}{l}0.48 \\
(0.22)\end{array}$ & $\begin{array}{l}540 \\
(60)\end{array}$ & $\begin{array}{l}65 \\
(8)\end{array}$ \\
\hline
\end{tabular}

BSA, body surface area; EDVI, end diastolic volume index; ESVI, end systolic volume index; SVI, stroke volume index; EF, ejection fraction; EDSI, end diastolic shape index; PFR, peak filling rate; tPFR, time to PFR; PER, peak ejection rate; SSW, systolic stroke work; CE, cycle efficiency.

This has previously been shown to be an accurate method of volume measurement that overcomes some of the geometric assumptions inherent in single plane derivations. The ventricle is divided into $\mathbf{4 0}$ elliptical slices and the major and minor dimensions of these are taken from each of the angiographic views. ${ }^{12}$ Several groups have used similar methods and have reported raised ventricular volumes and depressed ejection fraction in patients with tricuspid atresia, ${ }^{61617}$ but there have been few attempts to measure more sensitive indices of function or to compare function in these patients with those who have other forms of univentricular atrioventricular connection. Left ventricular end diastolic volume, corrected for body surface area, was similar in our patients with tricuspid atresia and those with double inlet left ventricle. As might be expected, however, the absolute values for end diastolic volume were considerably higher than normal in these ventricles receiving both systemic and pulmonary venous return. ${ }^{7}$ The ejection fraction in our patients with tricuspid atresia was similar to that reported with both angiographic ${ }^{47}$ and radionuclide techniques. ${ }^{518}$ Unlike other studies, however, we were unable to confirm any significant relation in our small study between ejection fraction and age, ${ }^{4}$ previous sys- temic-to-pulmonary shunt procedures, ${ }^{6}$ or systemic oxygen saturation. ${ }^{17}$ Indeed the finding of normal, and often supranormal, ejection fraction in the patients with double inlet left ventricle, of similar age range, haemodynamic function, and distribution of previous palliative procedures suggests that these factors may not be primary determinants of the reduced ejection fraction seen in patients with tricuspid atresia.

It is perhaps more likely in the light of our findings that the cause of the reduced ejection fraction in tricuspid atresia is structural. The normal left ventricle ejects a considerable proportion of its stroke volume by an alteration of its shape during systole. ${ }^{11}$ In a previous study this normal change in shape seemed to be much reduced in patients with univentricular hearts ${ }^{19}$ although in four patients, all with two atrioventricular valves, this change in shape seemed to follow more closely the pattern of the normal left ventricle. In our patients with double inlet left ventricle both the end diastolic shape index and the change in shape index during systole were similar to normal values. ${ }^{11}$ In contrast in tricuspid atresia the left ventricle was more globular at end diastole and changed little during systole; thus virtually all the change in cavity volume in these 
ventricles resulted from myocardial fibre shortening. It is possible that disruption of the normal myocardial fibre architecture, because of the absence of an atrioventricular connection, reduces the ability of the ventricle to change its cavity volume by changing shape. Indeed the ejection fraction and change in shape index were normal in a single patient studied with atrioventricular concordance and an imperforate right atrioventricular valve but otherwise similar haemodynamic function to classic tricuspid atresia (unpublished). The significant linear relation between change of shape and ejection fraction in our patients further supports this concept but cannot exclude a common, unrecognised, aetiological factor.

Frame by frame analysis of ventricular volume shows further differences in both systolic and diastolic indices of function. The peak rate of ventricular filling was significantly lower in patients with tricuspid atresia than in those with double inlet left ventricle. It is clear, however, that peak filling rate is higher in those with a double inlet than previously published normal values. ${ }^{20}$ It is possible that peak filling rate is higher than normal in these patients because the ventricle is filling through two atrioventricular valves. There was a significant relation between the $R R$ interval and peak filling rate in the double inlet group $(r=0.73)$, however, and it is likely that the increase in peak filling rate was related to the relatively high heart rate in these patients. There was no haemodynamic evidence of inflow obstruction in our patients with tricuspid atresia, either across the atrial septum or across the left atrioventricular valve, and so filling was probably impaired when compared with normal. The time to peak filling rate was also reduced in these patients and this combination of an early yet reduced peak rate of ventricular filling is similar to that seen in adults with a raised end systolic volume and reduced ejection fraction secondary to ischaemic cardiomyopathy. ${ }^{20}$

Despite the abnormalities described above the left ventricular pressure-volume loops showed a coordinate phase-relation between pressure and volume in most patients, and, apart from a single patient with reduced pulmonary blood flow and severe systemic desaturation, the cycle efficiency of the loops was normal. Systolic stroke work, equal to the area enclosed by the pressure-volume loop, was higher in the group with double inlet left ventricle simply because of the higher stroke volume in these patients.

The implications of these findings for corrective or radical palliative surgery are unclear. It has been suggested that normal preoperative ventricular function is an essential prerequisite for the Fontan operation or its modifications. ${ }^{3}$ Yet the survival of patients after these procedures appears to be higher in patients with tricuspid atresia than in those with double inlet left ventricle. ${ }^{8}$ It seems that in most young patients undergoing Fontan-like procedures. preoperative ventricular function is not a primary? determinant of survival. It is possible that the influence of preoperative ventricular function wils vary depending on the type of atrioventricular con $\frac{\bar{p}}{s}$ nection, however. Furthermore, it is not known how preoperative ventricular function will affect perfor mance in the survivors of these operations. We have increasing evidence that cardiac output and exercise tolerance are reduced after the Fontan procedure $\frac{2 \vec{L}}{\omega}$ but there are little data relating these findings to measurements of preoperative ventricular function A large scale longitudinal study of these patient:8 would help to answer some of these questions.

Our results show that ventricular function irif patients with tricuspid atresia is often worse than in those with double inlet left ventricle. These abnor윽 malities are more likely to be related to structurat differences rather than to differences in haemodyn응 amic function or the effects of previous palliative operation. The higher survival after the Fontan operation of patients with tricuspid atresia suggests. that ventricular function is not a primary determin $\rightleftharpoons$ ant of outcome after this procedure.

We thank Dr Derek Gibson, Mr Christopher Lin coln, Professor Robert Anderson, Dr Graham Miller, Mr David Hughes, and Mrs Susan Jones foD their help in the preparation of this study.

ANR is holder of a British Heart Foundation $\vec{b}$ grant.

\section{References}

1 Fontan F, Baudet E. Surgical repair of tricuspid atresia: Cardiovasc Surg 1982;83:427-36.

2 Kreutzer GO, Vargas FL, Schlichter AJ, et al Atriopulmonary anastomosis. $J$ Thorac Cardiovasion Surg 1982;83:427-36.

3 Choussat A, Fontan F, Besse P, Vallot F, Chauve $A_{b}$ Bricaud $H$. Selection criteria for the Fontan procedure. Pediatr Cardiol 1978;1:559-66.

4 Graham TP, Erath HG, Boucek RJ, Boerth RC. Lef: ventricular function in cyanotic congenital heart disease. Am J Cardiol 1980;45:1231-6.

5 Baker EJ, Jones ODH, Joseph MC, Maisey MN, Tynarf MJ. Radionuclide measurement of left ventriculart

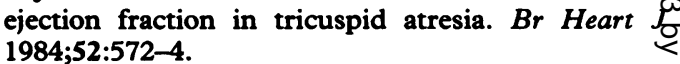

6 Lacorte MA, Dick M, Scheer G, LaFarge CG, Fyle DC. Left ventricular function in tricuspid atresia Circulation 1975;52:996-1000.

7 Redington AN, Knight WB, Oldershaw PJ, Dawson DR, Shinebourne EA, Rigby ML. Ventricular func? tion in double inlet left ventricle [Abstract]. Circu雨 lation 1986;74(suppl II):465.

8 Pacifico AD, Kirklin JK, Kirklin JW. Surgica 
management of double inlet ventricle. World J Surg 1985;9:579-89.

9 Rigby ML, Anderson RH, Gibson D, Jones ODH, Joseph MC, Shinebourne EA. Two dimensional echocardiographic categorisation of the univentricular heart. Ventricular morphology, type, and mode of atrioventricular connection. Br Heart $J$ 1981;46:603-12.

10 Rigby ML, Gibson DG, Joseph MC, et al. Recognition of imperforate atrioventricular valves by two dimensional echocardiography. Br Heart J 1982;47:329-36.

11 Gibson DG, Brown DJ. Continuous assessment of left ventricular shape in man. Br Heart J 1975;37:904-10.

12 Yettram AL, Vinson CA, Gibson DG. Computer modelling of the human left ventricle. Trans $A S M E$ 1982;104:148-52.

13 Suga H, Yamada O, Goto Y. Energetics of ventricular contraction as traced in the pressure-volume diagram. Fed Proc 1984;43:2411-3.

14 Gibson DG, Brown DJ. Assessment of left ventricular systolic function in man from simultaneous echocardiographic and pressure measurements. Br Heart J 1976;38:8-17.

15 Scott DJ, Rigby ML, Miller GAH, Shinebourne EA. The presentation of symptomatic heart disease in infancy based on 10 years' experience (1973-82). Implications for the provision of services. Br Heart $J$ 1984;52:248-57.

16 Shimazaki Y, Kawashima Y, Mori T, Kitamura S, Matsuda $H$, Yokota $K$. Ventricular volume characteristics of single ventricle before corrective surgery. $\mathrm{Am}$ J Cardiol 1980;45:806-10.

17 Nishioka $K$, Ueda $T$, Hayashidera $T$, et al. Left ventricular volume characteristics in children with tricuspid atresia before and after surgery. Am J Cardiol 1981;47:1105-10.

18 Hurwitz RA, Randall CL, Girod DA, Wellman H. Left ventricular function in tricuspid atresia: a radionuclide study. J Am Coll Cardiol 1986;8:916-21.

19 Gibson DG, Traill TA, Brown DJ. Abnormal ventricular function in patients with univentricular heart. Herz 1979;4:226-32.

20 Hui WKK, Gibson DG. Mechanisms of reduced ventricular filling rate in coronary artery disease. Br Heart J 1983;50:362-71.

21 Driscoll DJ, Danielson GK, Puga FJ, Schaff HV, Heise CT, Staats BA. Exercise tolerance and cardiorespiratory response to exercise after the Fontan operation for tricuspid atresia or functional single ventricle. J Am Coll Cardiol 1986;7:1087-94. 